\title{
Recognising, Safeguarding, and Promoting Food Heritage: Challenges and Prospects for the Future of Sustainable Food Systems
}

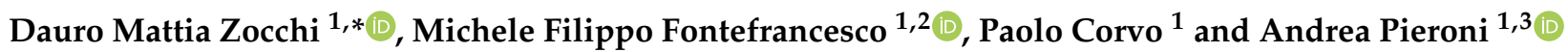 \\ 1 University of Gastronomic Sciences, Piazza Vittorio Emanuele II 9, 12042 Pollenzo, Italy; \\ m.fontefrancesco@unisg.it (M.F.F.); p.corvo@unisg.it (P.C.); a.pieroni@unisg.it (A.P.) \\ 2 Department of Anthropology, Durham University, Durham DH1 3LE, UK \\ 3 Department of Medical Analysis, Tishk International University, Erbil 44001, Kurdistan, Iraq \\ * Correspondence: d.zocchi@unisg.it
}

check for updates

Citation: Zocchi, D.M.; Fontefrancesco, M.F.; Corvo, P.; Pieroni, A. Recognising, Safeguarding, and Promoting Food Heritage: Challenges and Prospects for the Future of Sustainable Food Systems. Sustainability 2021, 13, 9510. https://doi.org/10.3390/su13179510

\section{Academic Editors: Theano}

Moussouri, Georgios Alexopoulos and Diana Rahman

Received: 8 July 2021

Accepted: 20 August 2021

Published: 24 August 2021

Publisher's Note: MDPI stays neutral with regard to jurisdictional claims in published maps and institutional affiliations.

Copyright: (c) 2021 by the authors. Licensee MDPI, Basel, Switzerland. This article is an open access article distributed under the terms and conditions of the Creative Commons Attribution (CC BY) license (https:/ / creativecommons.org/licenses/by/ $4.0 /)$.

\begin{abstract}
The safeguarding and promotion of food heritage are often considered as a possible way for achieving social and cultural sustainability objectives. This literature review investigates some of the dynamics underlying the heritagisation of food and explores the risks of this process. It focuses mainly on anthropological, geographical, and sociological publications. Overall, it aims to shed light on the strengths and limitations of food heritagisation regarding the improvement of the socio-cultural sustainability of the food system. The analysis highlights cross-cutting risks, namely the omission of tangible and intangible elements of the local food system, and the exclusion of key stakeholders from the recognition and institutionalisation of food heritage. The review highlights the strict interdependence between intangible and tangible elements during food heritagisation, and assesses how local and global interactions can activate and shape this process. It sheds light on the need to pay more attention to the factors, actors, and relationships underpinning the emergence and recognition of food and food-related elements as part of the local heritage.
\end{abstract}

Keywords: food heritage; heritagisation; social and cultural sustainability; literature review

\section{Introduction}

Food heritagisation "refers to the transformation of [food], places and practices into cultural heritage as values are attached to them, essentially describing heritage as a process" [1] (p. 26). In the recent decades, it has been at the centre of a growing attention. This attention is linked to the emergence of several initiatives aimed at recognising, safeguarding, and promoting tangible and intangible elements of the foodscape. In 2010, the inclusion of the Mediterranean diet, Mexican cuisine, and the gastronomic meal of the French in UNESCO's "Intangible Cultural Heritage of Humanity" list recognised the need to protect food and culinary cultures given their importance as identity markers, as well as their role in fostering the economic, political, and social empowerment of local communities [2,3]. This phenomenon has attracted the attention of social scientists, especially in the field of food studies. It is what Geyzen [4] called a "heritage turn", that is, the rise of a strand of research exploring the link between identity crises, attempts at reidentification, and the development of heritage-based projects linked to food and the gastronomic milieu. This has also been at the core of the debate in food and social sciences, especially with regard to the link between the promotion of local agri-food resources, rural development, and food tourism [5-7].

In the last few years, there has been a flourishing discourse on the relationship between food heritage and sustainability. The current discussion explores how the elevation of food to the status of heritage can enhance the sustainability of the food system while safeguarding traditional food resources through the active participation of local communi- 
ties [8-13]. More recently, there has been increasing attention to the relationship between food heritage and socio-cultural sustainability [14-17].

In the institutional fields, the safeguarding and promotion of food and cultural resources is considered a possible tool for achieving social and cultural sustainability objectives $[18,19]$. According to Thorsby [20], cultural sustainability involves the protection and maintenance of cultural values, practices and knowledge, and their transmission to future generations. Given the intrinsic link between this and the other pillars of sustainability (i.e., economic, social, and environmental), the promotion of cultural resources can contribute to the achievement of broader goals, such as improvements in the quality of life and well-being of society in general [21,22]. In this context, the promotion of food heritage can foster the development of inclusive processes to improve the socio-economic and health conditions of rural communities, while enabling the conservation of traditional food and cultural elements embedded in specific places [10,15]. Kapelari et al. [16] suggested that food heritage should play a central role in the design and implementation of sustainable development policies aimed at ensuring food security and sovereignty for the global population.

When considering the potential benefits of food heritagisation (e.g., strengthening of cultural identity, preservation of local knowledge and traditions, and improvement of the socio-economic conditions of local populations), several scholars have warned of possible contradictions underlying this process, such as the exclusion and marginalisation of particular groups of actors, triggering of cultural expropriation, loss of biological and cultural diversity, weakening and commodification of cultural identity, over-exploitation of local resources, and decrease in their availability within traditional networks of exchange and consumption [23-27].

To date, some studies have analysed the debate on "food as cultural heritage" in order to frame this concept and explore the perspectives of its valorisation (i.e., the process that aims at increasing the economic, social, and cultural value of a product) [28], as well as to define the main dimensions of heritage foods and identify some of the risk factors that may compromise their authenticity and food safety [29]. However, little attention has been paid thus far to investigating when food heritagisation and the valorisation of food heritage may fail in achieving social and cultural sustainability goals.

To partially fill this gap, we conducted a literature review with the aims of identifying some of the underlying dynamics of the heritagisation of food and investigating the variables that can shape the outcomes of this process. Some of the risks and unintended effects underlying this process were examined in order to answer the following research question: under what circumstances does official food heritagisation generate outcomes that reverberate negatively on the social and cultural sustainability of the food system?

The specific objectives of the review were to:

- $\quad$ explore different conceptualisations of food heritage and associated terms;

- identify some of the main events and activities underpinning the process of recognising, safeguarding, and promoting food heritage; and

- investigate the main risk factors and failures in the implementation of food heritagebased initiatives, focusing on the changes and alterations that shape social and cultural elements related to food and gastronomy.

Overall, the article wants to shed light on some elements that researchers should consider to reflect on the strengths and limitations of the official heritagisation of food with regard to the improvement of the socio-cultural sustainability of the food system, its associated actors, and resources.

The paper is organised as follows. Section 2 presents the methodology used to identify, screen, and review the literature. Section 3 outlines the conceptualisations of food heritage and its main features. Section 4 explores the main dynamics connected to the heritagisation of food that emerged during the review. Section 5 presents some relevant critical issues linked to heritagisation, paying particular attention to the recognition, legitimisation, and valorisation of food heritage. The unintended and negative effects of each issue are explored 
at a general level, as well as by presenting case studies that shed light on the causes and dynamics from which they may arise. Section 6 summarises the most relevant criticalities of the food heritagisation process and development of heritage-based projects, inferring how they might hinder the achievement of social and cultural sustainable goals. Section 7 introduces potential research trajectories to further explore the connection between heritage and socio-cultural sustainability in the food and gastronomic fields.

\section{Materials and Methods}

The article presents the results of a literature review aimed at investigating some interconnecting elements in the scientific debate on food heritage and food heritagisation.

Review papers are critical evaluations of studies that have already been published and whose main objective is "to provide a historical perspective of the respective research area and an in-depth account of independent research endeavours" [30] (p. 233). They can be carried out following different approaches. Common models used in the social sciences and specifically for assessing food and gastronomic-related issues [31,32] are systematic literary review and narrative review models. Both these models discuss a specific topic by integrating extant literature, synthesizing prior studies, identifying knowledge gaps, and developing new theoretical frameworks [33]. On the one hand, systematic literature reviews rely on formal mechanisms for the organisation and analysis of the literature. They are more suitable for exploring focused topics, often through quantitative analysis with the statistical pooling of data [34]. On the other hand, narrative reviews provide descriptive syntheses of previously published information [35] based on a more unstructured approach. For this reason, they have greater communicative potential both in terms of readability and to create a comprehensive theoretical framework in the face of a fragmented debate or an emergent topic [36].

Due to the nature of the research questions, the fragmentation of the debate, and the heterogeneity of sources, the article follows the model of a narrative literary review.

The literature review entailed four stages.

Stage 1: The literature was searched to explore the concept of food heritage and identify some of the main dynamics underlying the recognition food and gastronomic resources as "heritage", and concerning their safeguard and promotion. To this end, we carried out a semi-structured literature search in the Scopus, Ebsco, and Science Direct databases. A complementary search was done using bibliographic references found on the Google Scholar website.

Literature searches were conducted using the terms "food heritage", "heritage food", "gastronomic heritage", "culinary heritage", "food heritagisation", and "food patrimonialisation" in the article title, abstract, and keywords. The Boolean operators "AND" and "OR" were used so that a single search of each database included all of the search terms.

The results were filtered by focusing on scientific articles, books, and book chapters related to the socio-cultural analysis of food heritage and the heritagisation of food, focusing mainly on anthropological, sociological, and geographical works.

Inclusion criteria for materials were: abstract written in English, published in peerreviewed journals (for articles), and issued from 1998 (publication of Bessiere's influential article on food heritage and food heritagisation [5], which is currently the most-cited article on this topic) to April 2021 (present).

A screening exercise was then used to eliminate documents that did not explicitly relate to the heritagisation of food and its employment in the realm of the catering industry or the framework of rural development projects. After this process, we identified 81 documents as relevant for our research purposes. Table 1 summarises the general information of the materials considered for the analysis.

Of the 81 documents, 71 were journal articles and ten were books or book chapters. The articles were published in 41 different peer-reviewed journals, with $30 \%$ of them in the journals of Anthropology of food, Sustainability, Journal of Rural Studies, and Food, Culture and Society. 
Table 1. Summary of the analysed documents.

\begin{tabular}{ccc}
\hline Item & Number of Entries & Notes \\
\hline Numbers of documents & 71 & $\begin{array}{c}\text { Peer-reviewed journal articles } \\
\text { Books and book chapters }\end{array}$ \\
\hline Year of publication & 10 & $1998-2006$ \\
& 8 & $2007-2013$ \\
Number of authors & 21 & $2014-2020$ \\
\hline Number of affiliations & 52 & - \\
(universities and research centres) & 138 & - \\
\hline Number of journals & 95 & - \\
\hline
\end{tabular}

Stage 2: To conceptualise food heritage, the authors read and examined all the materials. Twenty-five documents were selected and analysed to explore the different definitions of food heritage and associated terms currently adopted in the debate and outline its main features.

Stage 3: The authors analysed all 81 documents using the qualitative data analysis software NVivo version 12.5.0 [37] to identify some of the events and activities underpinning the process of recognising, safeguarding, and promoting food heritage. This process identified three main groups of dynamics underpinning food heritagisation, namely "recognition", "legitimisation", and "valorisation". The main characteristics of each group are reported in Section 3.

Stage 4: To explore the risk factors and unintended effects of food heritagisation, the full texts of the relevant materials were read and assessed on the basis of the inclusion criteria, resulting in a final body of 45 documents. The selection focused on academic studies exploring national or international projects that combine the safeguarding of food and cultural elements with their valorisation. Specifically, documents exploring the topic of food heritage in the framework of initiatives promoted by UNESCO as well as by international and national bodies including the European Union, NGOs, and food movements were prioritised.

Subsequently, the data was analysed through a quality content analysis to identify the main critical issues related to the three processes [38]. To this end, the selected materials were classified and grouped into "heritage recognition", "heritage legitimisation", and "heritage valorisation" using the NVivo case function [39]. Afterwards, the documents were systematically coded and grouped into themes and sub-themes for each case study (the authors generated nodes and categories during the analysis) according to the main unintended effects.

\section{Exploring the Concept of Food Heritage}

The analysis of the 25 documents shows the difficulties of clearly defining the boundaries of food heritage. This circumstance is reflected in the heterogeneous and fragmented conceptualisations of this term.

Overall, the term food heritage acts as an umbrella concept that includes different definitions such as what can be defined as agri-food heritage, culinary heritage, and gastronomic heritage.

Some authors [40-42] adopt a conceptualisation of food heritage in line with the one proposed by Béssiere [5] (p. 27) that includes: "agricultural products, ingredients, dishes and cooking artefacts. It also comprises the symbolic dimension of food (table manners, rituals), techniques, recipes, eating practices and food-related behaviours and beliefs".

In other studies, agri-food heritage, culinary heritage, and gastronomic heritage are used as synonyms or interchangeably with food heritage and heritage food (i.e., the physical elements of food heritage such as local products and traditional equipment). 
However, as shown in Table 2, there are some differences in their specific meanings and conceptualisations.

Table 2. Definitions and related characteristics of food heritage, agri-food heritage, culinary heritage, and gastronomic heritage.

\begin{tabular}{|c|c|c|}
\hline Concept & References & Main Features \\
\hline $\begin{array}{c}\text { Food } \\
\text { Heritage }\end{array}$ & {$[5,40-42]$} & $\begin{array}{l}\text { - } \\
\text { - } \quad \text { Technicultural products, ingredients, dishes, and cooking implements } \\
\text { - } \quad \text { Symbolic dimension of food (e.g., table manners and rituals) } \\
\text { - } \quad \text { Eating practices, food-related behaviours, and beliefs } \\
\text { - } \quad \text { Shared legacy and common good }\end{array}$ \\
\hline $\begin{array}{l}\text { Agri-food } \\
\text { Heritage }\end{array}$ & [43-48] & $\begin{array}{ll}\text { - } & \text { Agricultural products } \\
\text { - } & \text { Production practices and traditional knowledge } \\
\text { - } & \text { Rootedness in rural and marginal areas (expressed by the category terroir) }\end{array}$ \\
\hline $\begin{array}{l}\text { Culinary } \\
\text { Heritage }\end{array}$ & {$[11,49-56]$} & $\begin{array}{l}\text { - Ingredients, cooking accoutrements, and recipes (corpus of culinary elements and strong } \\
\text { emphasis on practices) } \\
\text { - Tastes, smells, and eating traditions } \\
\text { - } \quad \text { Ethnic, national, and political dimensions } \\
\text { - } \quad \text { Sociability, legacy, identity, tradition, and sense of belonging }\end{array}$ \\
\hline $\begin{array}{c}\text { Gastronomic } \\
\text { Heritage }\end{array}$ & {$[3,6,8,28]$} & $\begin{array}{l}\text { - Products, practices, and knowledge related to the cultivation, harvesting, and conservation of } \\
\text { agricultural products } \\
\text { - Ingredients, cooking utensils, and recipes (corpus of culinary elements and strong emphasis on } \\
\text { practices) } \\
\text { - } \quad \text { Ethnic, national, and political dimensions } \\
\text { Sociability, legacy, identity, tradition, and sense of belonging }\end{array}$ \\
\hline
\end{tabular}

Agri-food heritage includes elements belonging to the upstream part of the foodscape. It focuses mainly on the relationships between agricultural products, production practices, and traditional knowledge linked to rural contexts. This link is often expressed by the category terroir [43-46]. Agricultural products (primary or processed) characterised by a strong rootedness in rural, often marginal areas represent the material element at the core of this concept $[47,48]$.

The term culinary heritage mainly considers elements and practices related to the preparation and consumption of food. Timothy and Ron [49] (p. 99) include in this definition "a mix of tangible (e.g., ingredients and cooking accoutrements) and intangible (e.g., tastes, smells, recipes and eating traditions) elements that contribute to the cultural values and characteristics of places". A strong emphasis is given to socio-cultural elements attached to the culinary sphere [11,50], its ethnic or national dimension [51], and its role as an identity marker [52]. Some definitions also denote the centrality of the continuity and evolution of practices and knowledge, as well as their intergenerational transmission [53].

An analogy with the definition of intangible cultural heritage proposed by Unesco [18] is evident in the focus on a corpus of culinary elements (more rarely individual dishes or recipes), a strong emphasis on practices, regional or national boundaries of heritage, and its marked political connotation [54-56].

The concept of gastronomic heritage takes on a similar meaning, especially with regard to the role of elements such as sociability, legacy, identity, tradition, and sense of belonging $[3,28]$. However, it has a more comprehensive dimension that can include products, practices, and knowledge related to the cultivation, harvesting, and conservation of agricultural products $[6,8]$.

Despite the differences and variability, it is possible to identify some common elements that the different conceptualisations share. First, they pay attention to physical objects embedded into well-defined geographical areas and cultural milieu. They are products or 
dishes linked to the public sphere and very often exchanged in market networks. Another commonality entails the formal connotation of heritage. In other words, material and immaterial elements of the foodscape become heritage elements following a process of official attribution of this status. There is, therefore, a prevailing focus on the process (i.e., heritagisation) and its dynamics rather than on the physical object (i.e., products and dishes).

\section{Framing the Process of Food Heritagisation and Its Socio-Cultural Nature: From Recognition to Valorisation}

Drawing from the analysis, food heritagisation can be conceived as the socio-cultural process through which different agents identify food and gastronomic resources embedded in a given place, attach new values to them, and formally recognise them as part of their collective heritage in an attempt to pursue their specific aims [24,51,57].

Bessière [5] underlines the ever-changing nature of food heritage and defines food heritagisation as a process and social practice that is constructed more than fixed. She frames it as the dynamic actualisation, adaptation, and reinterpretation of elements from the past attached to a given group, its knowledge, skills, and values.

\subsection{Heritage Recognition}

In their work, Bessière [5] (p. 28) and Bessière and Tibère [6] (p. 282) argue that food heritagisation underlies three different dynamics, namely "heritage realisation", "heritage awareness", and "heritage identification". Heritage realisation arises when a group of actors acknowledge the existence of a shared vision and judgement on some elements of the foodscape. Heritage awareness and identification occur when actors recognise their importance, identify "collective heritage objects", and eventually undertake a path towards their protection.

According to several authors, the relationships that develop in the globalised postmodern society are one of the main factors behind the recognition of food as cultural heritage $[4,49]$.

Some of the possible drivers of this phenomenon include the erosion of biological, cultural, and culinary diversity, and a decrease in the presence and change in the role of food and gastronomic resources $[15,58]$. These dynamics can stem from changes triggered by the industrialisation of the food system and some underlying effects such as the standardisation and homogenisation of foodscapes $[40,59]$, as well as the introduction of regulations that undermine the survival of traditional production systems [44,60].

A similar situation can occur in the face of rapid political, economic, and social changes [51,61,62]; environmental crises [9,46]; or following health and safety issues related to the food sector $[48,63]$.

The stress resulting from these events can foster a need to fill a sense of nostalgia for bygone food and culinary worlds [54] to counteract the perceived loss of identity and sense of alienation that stem from these dynamics $[50,64,65]$.

Disruptive events may prompt the development of these feelings when cultural and emotional connections, even though rarefied, between local communities and specific elements of the foodscape are still vivid [11,44,66,67].

The triggering of these reactions requires certain preconditions, such as changes in the social context including the development of urban middle classes; emergence of gastronomic and cultural elites; as well as improvements in the political and economic situation, for instance, in post-conflict and post-crisis times [13,41,62].

Moreover, increasing interactions between local and global networks can activate the process of heritage realisation. In fact, heritage realisation often occurs via an encounter with a form of social diversity that forces actors to rethink their value system [5]. Phenomena such as migrations [42,49] and growing international interest in local food and food-related experiences (e.g., food tourism in rural regions) $[17,68]$ can mobilise actors in the process towards the recognition of food as part of their collective heritage. 
The transition from realisation to awareness and eventual identification entails the participation of heterogeneous groups of actors in the selection of the heritage components and a value system to define their attributes [5] (p. 26).

The process follows a top-down path when food heritagisation is embedded in state campaigns aimed at affirming the national identity and creating a sense of belonging among members of the society [51,69]. This strategy is also an endeavour to compete in a global scenario by branding the nation through the deployment of distinctive traits of the food culture [52,70,71].

Local, national, and international actors (e.g., NGOs and national and regional administrations) undertake a similar path when they foresee the safeguarding and valorisation of food and cultural elements as a tool to foster the socio-economic development of marginalised regions $[8,10,66]$.

Heritage recognition follows a bottom-up approach when it stems from the reactions of local actors against negative dynamics affecting local food systems. In these cases, the intervention of food associations or movements (either local or international) can support and activate the path towards the safeguarding and promotion of heritage $[43,72,73]$.

In both circumstances, the heritagised object undergoes a process of reinvention and resignification that changes its meaning both for the community and for a wider range of local and extra-local actors. Internal or external experts (e.g., chefs, food entrepreneurs, and food activists), by acting as social and cultural brokers [74], can play a crucial role in drawing attention to this issue, expanding its visibility to a broad spectrum of society, and conveying new values to elements of the foodscape [75-77].

\subsection{Heritage Legitimisation}

The identification of collective heritage objects can engender an institutional acknowledgment of their "genuineness and authenticity" [5] (p. 28). Bessière and Tibère [6] call this stage "heritage legitimisation", the process through which various actors officially recognise it as part of the collective heritage (i.e., internal legitimisation process). Legitimisation also has the function of authenticating heritage objects externally (i.e., external legitimisation process).

The legitimisation and authentication of heritage require a strong interconnection between endogenous and exogenous elements, and local and extra-local actors. Cohen and Cohen [78] identify two modes of authentication, namely "cool" and "hot". Hot authentication involves local actors-bearers of the knowledge associated with the heritage object-in the recognition and definition of its features. Cool authentication concerns the official attribution of the status of heritage by experts and authorities or, as Smith [79] defines, by authorised heritage discourse.

This authorised heritage discourse is more prominent in the recognition of food heritage through the inscription of food-related elements to heritage inventories such as the UNESCO ICH list [51,56]; its certification with food quality schemes including geographical indications (GI) $[45,80,81]$ and local agro-food systems (LAFS) [9]; or its recognition by food movements such as Slow Food [64,82-84].

Legitimisation involves the definition of the tangible and intangible boundaries of the heritagised food, as well as the codification, certification, and institutionalisation of its associated physical features.

\subsection{Heritage Valorisation}

In some circumstances, legitimisation can lead to the creation of new economic opportunities for local communities (e.g., value chains and food tourism). This can happen when the heritagised element is a food traditionally intended for subsistence or is marketed through informal networks $[47,50]$.

On other occasions, legitimisation occurs when the resource already has a commercial value, at least at the local level. This circumstance may arise in the face of an expansion and 
increasing formalisation of the market $[81,85]$. The shift from local to extra-local markets prompts the need for heritage protection [40,52].

The valorisation of food heritage involves a process that intentionally alters the value and meanings of a component of the foodscape to improve its position within a given social context and, in so doing, increases its prestige and desirability [8].

The attention of scholars towards this topic (i.e., the utilisation of food heritage as a socio-economic endeavour) stems from the multifunctional benefits linked to the recognition of this status to food $[3,54]$. The promotion of local and traditional agrifood and gastronomic resources has been highlighted as a strategy to promote improved socio-economic conditions for indigenous and rural communities through the sustainable use of local resources [86]. Recognising, safeguarding, and promoting traditional foods can also contribute to the revitalisation of local food and gastronomic practices, as well as the associated knowledge [72,87], the protection of local biodiversity [88], and the empowerment of communities through the localisation of control over resources [89].

\section{Possible Side Effects and Critical Issues of Food Heritagisation}

During the quality content analysis, the authors analysed 45 documents in order to highlight specific variables that can trigger unintended effects whose impacts reverberate negatively on social and cultural elements of the local foodscape. The selected materials were coded and grouped into three themes and seven sub-themes.

Table 3 summarises the main findings of the analysis concerning risks and criticalities during heritage recognition, legitimisation, and valorisation. The references to the documents are reported in the table according to the main unintended effects and causes that the authors identified during the analysis.

Table 3. Summary of the main criticalities identified during the analysis in the processes of heritage recognition, legitimisation, and valorisation.

\begin{tabular}{|c|c|c|c|}
\hline $\begin{array}{l}\text { Food } \\
\text { Heritagisation } \\
\text { Processes }\end{array}$ & References & Unintended Effects & Main Causes \\
\hline \multirow{3}{*}{$\begin{array}{c}\text { HERITAGE } \\
\text { RECOGNITION }\end{array}$} & {$[40,64,84]$} & $\begin{array}{l}\text { Frictions and } \\
\text { conflicts }\end{array}$ & $\begin{array}{l}\text { Misinterpretation of the drivers behind } \\
\text { heritage realisation } \\
\text { Irreconcilability of the meaning and role } \\
\text { attributed to food heritagisation }\end{array}$ \\
\hline & {$[4,40,55,62,65,85,90-92]$} & $\begin{array}{l}\text { Homogenised } \\
\text { representations of } \\
\text { food and } \\
\text { gastronomic } \\
\text { diversity }\end{array}$ & $\begin{array}{l}\text { - Frictions between the dynamism of food } \\
\text { culture and the static notion of heritage } \\
\text { Adoption of global heritage models that } \\
\text { cannot grasp the specificities of the local } \\
\text { place }\end{array}$ \\
\hline & {$[23,41,51,62,69,75,76,93-95]$} & $\begin{array}{l}\text { Marginalisation and } \\
\text { distortion }\end{array}$ & $\begin{array}{l}\text { Top-down approaches and unbalanced } \\
\text { power relations between promoters and } \\
\text { heritage bearers } \\
\text { - } \quad \text { Limited control of local communities over the } \\
\text { identification of collective heritage objects } \\
\text { - Distorted, idealised, and stereotyped } \\
\text { representations of food and gastronomic } \\
\text { diversity }\end{array}$ \\
\hline
\end{tabular}


Table 3. Cont.

\begin{tabular}{|c|c|c|c|}
\hline $\begin{array}{l}\text { Food } \\
\text { Heritagisation } \\
\text { Processes }\end{array}$ & References & Unintended Effects & Main Causes \\
\hline \multirow[b]{2}{*}{$\begin{array}{l}\text { HERITAGE } \\
\text { LEGITIMISATION }\end{array}$} & {$[25,40,45,47,64,85,96-99]$} & $\begin{array}{l}\text { Standardisation and } \\
\text { homogenisation }\end{array}$ & $\begin{array}{l}\text { Exogenous models, poor adaptability to the } \\
\text { local foodscape, and scarce protection of } \\
\text { heritage bearers } \\
\text { - Standardisation and loss of both diversity } \\
\text { and variability of food and cultural systems }\end{array}$ \\
\hline & {$[9,53,66,80-83,90,100-102]$} & $\begin{array}{l}\text { Exclusion and } \\
\text { co-optation }\end{array}$ & $\begin{array}{l}\text { - Excessive influence of external players in the } \\
\text { codification of food heritage } \\
\text { Poor adaptability of production and legal } \\
\text { standards to the local production realities }\end{array}$ \\
\hline \multirow[b]{2}{*}{$\begin{array}{c}\text { HERITAGE } \\
\text { VALORISATION }\end{array}$} & {$[11,40,47,60,83,85,103,104]$} & $\begin{array}{l}\text { Loss of traditional } \\
\text { values and } \\
\text { relationships }\end{array}$ & $\begin{array}{l}\text { - Commodification and alterations of the } \\
\text { socio-cultural values of food heritage } \\
\text { Market feedback and its impact on the } \\
\text { traditional production and social system }\end{array}$ \\
\hline & {$[9,50,68,69,75,82,85,93,95]$} & $\begin{array}{l}\text { Loss of control over } \\
\text { and access to } \\
\text { heritage resources }\end{array}$ & $\begin{array}{l}\text { - Increase in the competition of powerful } \\
\text { economic actors and risk of co-optation } \\
\text { Decrease in product availability within } \\
\text { traditional exchange and consumption } \\
\text { networks }\end{array}$ \\
\hline
\end{tabular}

\subsection{Dynamics of Risk during Heritage Recognition}

The main aspects explored in the debate on heritage recognition entail the analysis of the drivers behind this process, the expected outcomes, and the understanding of the discourses and representations that stems from the heritagisation process, as well as the actors, the relationships between them, and the role they play in the heritage process.

According to the literature analysis, the main criticalities may occur during the identification of collective heritage objects in the face of divergences in the perspective of the agents involved in it. This situation can, in turn, lead to the oversight of the specificities of local food and gastronomic contexts; an a priori exclusion of material and immaterial elements from their recognition as heritage; and the physical and symbolic appropriation of products, practices, and knowledge by powerful local or extra-local actors.

\subsubsection{Heterogeneity, Frictions, and Failures}

In their study of heritage-based food systems in France and Poland, Bowen and De Master [40] showed that conflicts may emerge when extra-local actors value aspects of food and culinary traditions differently from local actors and try to impose their view regarding the motivations for, as well as the expected outcomes of, heritagisation.

In her analysis of the heritagisation of pinole (a traditional Mexican sweet), Littaye [84] emphasised the influence of external actors in activating the process towards the recognition and rediscovery of this heritage food. Specifically, she shows the key role of the Slow Food movement in recreating and shaping the symbolic value of pinole. In doing so, she warns of the limits of building a representation of food heritage that is not aligned with the perspectives of local communities and does not grasp the local-global connections behind the revival of this product.

Badii [64] examined the heritagisation of the Zolfino bean in Tuscany and showed how circumstances of this kind can generate representations of heritage that convey a distorted image of the specificities of a product and its embeddedness in the local food systems. In 
this case, the irreconcilability of the vision promoted by Slow Food and the present socioeconomic dynamics surrounding the production of this legume have triggered frictions between local actors that eventually caused the failure of the project.

\subsubsection{Homogenised and Partial Representations of Food and Gastronomic Diversity}

Selecting and recognising elements of the foodscape as official heritage may generate partial and distorted representations of its complex nature. Two interrelated factors may prompt this situation, involving the friction between the dynamism of food culture and the static notion of heritage, and the embracement of viewpoints that cannot grasp the local specificities.

Some authors highlight the tendency to adopt "particular (fixed) markers of culture over a more dynamic relationship between communities, environments, and local actors" [40] (p. 79) and the inclination to immobilise food culture rather than confronting its hybrid and evolving nature [55]. Overly static conceptualisations of heritage risk freezing tradition $[65,90,91]$ and reduce food and cultural diversity to a stereotypical representation of local identity [4]. This circumstance may stem from the adoption of universal models in the identification and selection of food heritage [85]. In his analysis of the heritagisation of Danish gastronomic culture, Gyimóthy [92] warned that this approach can risk falling into what he calls the "conformity trap". By focusing on globally recognisable and appreciable elements, heritage-based projects fail to capture the specific features of the regional foodscape and transform diversity into a homologated product.

The tension between the dynamism of the food milieu and the stasis of heritage may also result in partial representations of local gastronomic diversity. Sammels [62] (p. 345) shed light on this situation by looking at two different parts of the foodscape: the culinary field and the gastronomic field. Culinary fields are "the spaces of everyday cooking, eating, and commensality - the place where cooks' culinary talent and knowledge intersects with their familiarity with those who will be eating by accommodating their preferences, desires, and temporalities". The gastronomic field is, instead, "grounded in the authority of elite restaurants, written recipes, and food critics". As discourses on food heritage develop mainly in this latter field, there is a risk of excluding a priori the portion of food culture linked to the domestic and informal spheres, and, in so doing, obscuring the actors and the knowledge embedded in these systems.

\subsubsection{Marginalisation and Exclusion}

Food heritagisation implies a repositioning of products or practices and their associated values, which can result in a reinvention and re-imagination of food and culinary traditions [23].

Under specific circumstances, new representations can trigger marginalisation processes, leading to the symbolic and physical appropriation of products and knowledge, and, therefore, exacerbating socio-economic and cultural inequalities. The symbolic reinvention and reimagination of food culture may trigger phenomena of cultural expropriation, increase the feeling of exclusion for some actors, and limit the protection of their knowledge and identity.

Some authors have observed these situations in the revival of poverty foods and heirloom foods (i.e., foods commonly grown in the past but marginalised by present industrialised agriculture) $[93,94]$. In his analysis of the reinvention of Carolina Lowcountry cuisine, Jones [75] pointed out how the gastronomic elites followed a purified narrative to revive local heritage grains. In order to increase their appeal to wealthy consumers, they omitted the "unsavoury aspects" of these crops, including the slavery of the people who traditionally ate them. Even McDonell [76] in her study on the Peruvian gastronomic boom observed that the rediscovery of native foods entails a historical and spatial recontextualisation, as well as their appropriation by influential members of the national culinary scene (i.e., urban celebrity chefs). 
Scholars have investigated the dynamics of inclusion and exclusion underlying food heritagisation, looking at the extent to which politicised and elitist approaches can exacerbate social, economic, and cultural disparities [62,95].

When the recognition of food as heritage is based on the taste of a global audience and urban elites, it risks blurring the identity and cultural values of the product and marginalising the role of the communities that have traditionally safeguarded the product.

In his analysis of the Peruvian gastronomic boom, Matta [41,51] explained that marginalisation can arise from a process of "re-appropriation". This is achieved by removing the product from its context of origin, identifying some of its positive attributes, and finally associating them with elements from new culinary cultures.

Grey and Newman [69] identified similar issues in the incorporation of indigenous cuisine into the cultural heritage of Peru and Canada. They highlighted how the process of de-indigenisation and reinterpretation of culinary cultures carried out by non-indigenous chefs and national governments dilutes the culinary identity of native communities and leads to few tangible benefits for their livelihoods.

\subsection{Dynamics of Risk during Heritage Legitimisation}

The main risk stemming from heritage legitimisation develops around two factors: the physical transformations of food and food-related elements and the dynamics of inclusion and exclusion underlying the official regulation of food heritage.

Situations of this kind are often a consequence of the limited adaptability and applicability of universal heritage models and associated categories.

\subsubsection{Standardisation and Homogenisation}

Some contributions explore the limits of adjusting local specificities to what Grasseni [85] (p. 40) defined as "global standards of good practice", noting the limited effectiveness of this alignment [80].

The protection and enhancement of food heritage require a certain degree of standardisation of a product and the associated production system. According to Grasseni [25], standardisation does not eliminate diversity but, through a process of "calibration", it selectively organises material aspects as well as social and cultural practices. However, the rigidness of imposed norms and standards runs the risk of just ending up in the "global showcase of differences" [64] (p. 143).

While diversity is the backbone of food and cultural systems, production systems that present a high degree of variability are more difficult to codify [41]. This characteristic can undermine their effective safeguarding and increase the risk of conflicts between the actors involved in the process [96].

In their work on the Appellation d'origine contrôlée (AOC) label for Corsican cheese, Bowen and De Master [40] observed the difficulties of standardising the production process of a product that has historically been characterised by a high degree of variability. If standardisation can prevent a product from being co-opted by extra-local actors and guarantee its authenticity, it may threaten the diversity associated with the traditional production systems.

Berard et al. [45] studied the implementation of a protected designation of origin (PDO) for the Salers cheese in France and observed how the variability of dairy production techniques and practices, as well as the coexistence of unrelated production and knowledge systems (i.e., modern and traditional), clashed with the identification of a univocal version of the production protocol. This impasse inhibits cohesion between local producers and weakens the development and effectiveness of the enhancement project.

5.2.2. Between Innovation and Conservation: Static vs. Dynamic Approaches to the Legitimisation and Promotion of Food Heritage

Analysis of the dynamics underpinning the official recognition and legitimisation of food heritage sheds light on the frictions between conservation and innovation. 
Demossier [97] (p. 125) noted the contradictory nature of the safeguarding and promotion of food heritage, highlighting the contrast between the tendency to fix "traditional ways of doing things" and the marked inclination to foster modernisation.

An overly conservative approach may have unexpected outcomes on the diversity of the production system [40]. It can also disrupt the processes of socialisation and innovation that mark the evolution of local knowledge and practices [90]. As a consequence, there is a risk of triggering what Barham [98] (p. 132) called the phenomenon of "Disneyfication", turning food practices and products into a kind of "rurality under glass".

An innovation-driven approach can lead to the erosion of traditional production practices and the homogenisation of product qualities [82], as well as to the disruption of social and spatial relationships of the production system [83].

Zocchi et al. [99] observed this latter dynamic in their study of the Ogiek Honey Slow Food Presidium, a multi-actor project aimed at safeguarding and promoting traditional beekeeping heritage in the Ogiek of the Mau Forest in Kenya. In their study of the impacts of technological innovation on the beekeeping-associated ethnobotanical knowledge, they discovered how the introduction of innovative input (i.e., modern beehives) aimed to increase the production of honey, run the risk of dissociating beekeeping from the forest, and weaken the material and cultural links that tie Ogiek beekeepers to the forest.

\subsubsection{Institutionalisation, Exclusion, and Co-Optation}

As far as the delimitation of the material and intellectual property of food heritage is concerned, problems may arise during the codification process (i.e., the first step towards the formal recognition of the attributes of heritage foods and associated systems). When there is imbalance in the power relations between the heritage bearers and the other agents involved in this activity [40,64], this process can trigger exclusion or self-exclusion phenomena.

As Vitrolles [66] pointed out in her analysis of the geographical indication for Brazilian Serrano cheese, when the codification process does not adequately involve local actors, there is a risk of defining product quality on principles that are easily measurable and certifiable, but which do not capture the diversity and variability of the product itself. In other words, a lack of control by local communities in this process can lead to the omission of local knowledge and the expropriation of the advantages of heritagisation by players from the outside.

The inadequate engagement of local stakeholders may also hinder the sense of belonging to the project and trigger self-exclusion of the targeted beneficiaries. According to Dabezies [90] (p. 10), this situation can generate a condition of "heritage saturation" that fosters a negative feeling in local actors towards the promoters of the heritage process, whose actions are perceived as a limit to their autonomy. In his study of the heritagisation of the products derived from the butia fruits in Uruguay, the codification of local knowledge into standardised recipes, based on exogenous criteria, exacerbated this feeling among the producers, pushing them to leave the project.

Legitimisation grants a specific group of people common but exclusive rights over selected elements of the foodscape, turning them into limited common property [53] (pp. 68,69). The risk of increasing inequalities can stem from the legal regulation of heritage that is transforming traditional practices into community law and converting them into private or state property. This situation is more likely to happen when private or state entities convert heritagisation into what Cox Hall [100] (p. 337) called an "extractivist process" that generates income from heritage rather than strengthen collective identity and social cohesion.

The formal certification of food heritage can also trigger the marginalisation of those actors who are not able to comply with the rules and criteria guaranteeing its quality and authenticity [80,101,102]. Barrionuevo et al. [9] documented this situation in their analysis of the institutionalisation of Tandil cheese in Argentina. They observed how the lack of fit between legal and hygiene standards and local production realities favoured powerful 
extra-local actors who co-opted the advantages of heritagisation, pushing a progressive standardisation of the production system.

\subsection{Dynamics of Risk during Heritage Valorisation}

Scholars have explored heritagisation as a business strategy [42,70] and investigated the consequences of the commodification of food products and cultural practices in the framework of heritage-based projects. Specifically, valorisation is perceived as that precise moment when moral and cultural elements acquire a monetary value $[53,57,64]$.

In this debate, much attention has been paid to the unintended effects of an increase in commercial value and adaptations to the new market dynamics on the conservation of socio-cultural values attached to the traditional food system. Scholars have also explored the impacts on the physical and symbolic control of local communities over the heritagised resources, as well as on their availability within traditional networks of exchange and consumption.

\subsubsection{Eroding Traditional Values and Relationships}

The entry of the products into new social and economic networks requires adaptations to consumer tastes and regulations posed by the institutional actors therein [103].

Following these changes, tensions can emerge between the objectives of safeguarding food heritage and fostering its valorisation. In fact, these modifications can trigger transformations in the identity role of the product that, in turn, can lead to the loss of traditional elements or the development of new representations of tradition that supplant the tradition itself $[11,75]$.

Macdonald [83] (p. 94) noted this situation in his study of the heritagisation of Bulgarian green cheese by the Slow Food movement, highlighting how the attempt to safeguard the local relationships associated with "morally and aesthetically good" products clashes with their introduction into trans-local networks of regulation and consumption.

Alignments with market requirements can increase the tension between the identity and quality of heritage foods [47], alter the very nature of products [40,85], and restrict the use of traditional production practices [60].

Zocchi et al. [104] highlighted that modernisation of traditional production systems does not always translate into commercial advantages for local communities. In their study on the valorisation of forest honey among the Ogiek beekeepers in Kenya, the authors show how the attempt to align the product to alleged national and international tastes may undermine the specificities of locally produced honey, running the risk of losing its social and territorial embeddedness. This situation also exposes beekeepers to the competition of other products already in the market. Moreover, the research highlights the poor emotional and cultural attachment of local beekeepers to honey harvested with modern beehives compared to that produced from traditional log hives, whose maintenance would be significant in the food culture of the Ogiek people and in the conservation of the forest ecosystem.

\subsubsection{Losing Control over and Access to Heritage Resources}

If the revival of heritage and heirloom foods can increase their cultural and monetary value, this transformation brings to the forefront social justice [74] and food sovereignty issues [9]. Indeed, price inflation can exclude people from enjoying these products [95] and exacerbate the marginalisation of communities that have long been the custodians of the ingredients and associated traditions.

In their analysis of the dynamics behind the revival of traditional cuisine in Nakuru County, Kenya, Zocchi and Fontefrancesco [68] showed that the inclusion of heirloom vegetables in the regional restaurant sector, prompted by a growing demand for natural and healthy products by middle and high-income customers, implied a localisation of food supply chains based on self-production of these crops. Although this practice has a positive impact on a segment of the regional restaurant sector, it does not foster the creation of 
networks between the stakeholders of the local food system. This situation sheds lights on the risk of concentrating the economic benefits of this revival in the hands of a small proportion of food actors that can adapt to the demand and needs of the new customers.

West and Domingos [82] found a similar situation in the revival of SerpaVelho cheese by Slow Food. The attempt to convince local producers to rescue this product by increasing its market value clashed with the low spending capacity of local customers. Slow Food therefore did not succeed in de-commodifying this product but risked turning it into an expensive niche product, accessible only to a few consumers, often far from the context of production.

The transformation of foods traditionally linked to subsistence and local diets into rare and exotic goods for the global gourmet market often entails their disconnection from the original socio-ecological and cultural context of belonging $[44,69,93]$. The shift from local to extra-local markets may lead to a loss of control over the meanings and benefits of traditional products, as well as a decrease in their local availability. When a product enters new marketing circuits, it undergoes changes in its tangible and intangible features to improve its attractiveness to the new customers. In this process, neoliberal market forces and actors can mutate the original meaning of heritagisation and erode the values of precise symbols and cultural practices $[73,85,95]$.

\section{Discussion}

This study focuses on food heritagisation and the valorisation of food heritage with the aim of reflecting on their potential impacts on the social and cultural sustainability of food systems. In this regard, several points can be inferred from the literature analysis.

The first element to emphasize entails the concept of food heritage. The analysis highlights the absence of a shared definition of intangible heritage regarding food and gastronomy. Although the review identifies some conceptualisations that frame heritage in the food and gastronomic domains, it also shows the high degree of fragmentation of the debate. The findings are in line with what has already been observed by De-Miguel-Molina et al. [28] who highlighted how the concept of food heritage from a theoretical point of view is still in progress.

As already stated by other scholars [4,41,70], a thorough understanding of food heritage would benefit from a change and expansion of perspective from what makes up food heritage to the dynamics and motivations behind the recognition of food heritage.

By assuming that heritage is a socially constructed concept $[105,106]$ and perceiving heritagisation as a multi-directional process that shapes the foodscape [107], the research investigated the manner in which objects and practices acquire this status. It also explored what economic, political, and social factors drive this phenomenon.

The underlying assumption is that food heritagisation is a complex phenomenon that can alter material and immaterial elements of a given food and cultural system in so many ways that the range of possible outcomes becomes difficult to predict. In this regard, the findings show that the variability in the results of food heritagisation is strictly linked to the strong embeddedness of this process in contextualised socio-economic, political, and cultural dynamics, and in their evolution across time and space.

Bearing this in mind, the review explored specific actions underpinning food heritagisation and some cross-cutting factors that can undermine the positive outcomes of the safeguarding and valorisation of food heritage. In this respect, it identified two overarching risks, namely the omission of tangible and intangible elements of the local food system and culture, and the marginalisation or exclusion of key stakeholders from the heritagisation process.

Focusing on the analysis of heritage recognition, legitimisation, and valorisation, how the outcomes of these processes may hinder the improvement of the social and cultural sustainability of a food system emerges.

Overall, the study warns that under specific circumstances, official heritagisation and valorisation of food heritage run the risk of disrupting cultural values, practices and 
knowledge, and their transmission, undermining the achievement of inclusive and equal improvement of the well-being of the society.

Although these issues are more common during the valorisation phase, they already begin to appear during the identification and recognition of food heritage, especially following interactions and confrontations between local communities and other actors (often exogenous to the local context). These problems can increase during legitimisation and eventually with valorisation. To understand the factors behind the side effects of heritage valorisation, it is therefore crucial to analyse the dynamics underlying the recognition and legitimisation of food heritage.

As far as heritage recognition is concerned, the majority of the critical issues seem to arise during the shift from heritage awareness to identification, and as a result of scarce consideration of the events triggering heritage realisation.

A key aspect to understanding these circumstances lay in the relations of power underpinning the selection and representation of food as heritage. This is especially evident for heritage-based campaigns that utilise food to brand the country in a global scenario. In these circumstances, the identification of collective heritage objects, by reflecting the intentions of supra-local political bodies, inhibits the active participation of local communities and reduces the variety of food and cultural elements worthy of attention. The analysis identifies similar issues in the framework of international heritage-based projects due to the rigidity of their criteria and their strong focus on globally recognisable food resources.

These approaches to food heritagisation show the imbalance in power and roles between local actors and external agents, as well as significant influences of a "global hierarchy of value" [108] in the recognition of food as cultural heritage. Inequalities are also evident in the position that specific agents have in reimagining and representing food as collective heritage, and in the unfair redistribution of the benefits of these actions. The review highlights this circumstance for the position that celebrity chefs and governmental bodies play in the revival of traditional foods and native cuisine.

While heritagisation can hardly disregard the interaction with extra-local agents [3] and the inclusion of the local foodscape in trans-local networks [42], limited involvement of community members can increase the risk of essentialising and reifying food and cultural identity $[60,64,90]$. It also exacerbates the feeling of discrimination and fails to capture the diversity and variability of living heritage.

From this perspective, food heritagisation may fail in improving the social and cultural sustainability of the food system when it is deployed as an endeavour to boost gastronationalistic projects [109]. It can also happen when it follows global heritage models applied according to a "band-aid approach" [80] (p. 239). Indeed, it is more likely that food heritagisation blurs the diversity and variability of local identity, alters the embeddedness of food in a given social and cultural space, and limits its social inclusivity and empowerment capacity.

Looking at heritage legitimisation, the main issues that could limit the social and cultural sustainability of food heritagisation emerge during the process of standardisation, codification, and institutionalisation. Under specific circumstances, these actions may undermine the empowerment of heritage bearers and deny them adequate agency in heritage-based projects. This can, in turn, limit the social equity and inclusiveness of this process.

These dynamics are more likely to occur when top-down approaches drive food heritagisation, largely due to the lack of fit and flexibility of the logics behind the formalisation of property and rights on local food-related resources. These circumstances are more pronounced for exogenous heritage-related initiatives considering their adoption implies a translation process that does not always allow for negotiation between global and local perspectives. In doing so, they risk triggering symbolical and physical appropriation of local resources. In this regard, the review warns against the risk of falling into a "institutional monocropping" trap [110], in which the set of rules established in a specific context is grafted onto different societies and expected to yield the same results. 
The analysis also highlights the interdependence between physical adjustments in production systems and their impacts on the conservation of cultural links and social practices. Specifically, it sheds light on the ways in which formalisation and standardisation processes can disrupt socialisation and innovation dynamics embedded in local practices and knowledge. This can, in turn, affect their transmission to future generations, sparking a debate on the cultural sustainability of food heritagisation.

As reported by some scholars $[9,15,16,33]$, sustainable development assumes that all stakeholders should benefit from intervention projects aimed at safeguarding and promoting food and food-related resources. In this respect, the literature analysis shows that the valorisation of food heritage may clash with social sustainability objectives, bringing to the forefront issues of sovereignty, inclusion, and access and fair distribution of the benefits of this activity. These circumstances are more likely to emerge in the process that Grasseni [111], defined as "heritage commodification", namely the modification and adaptation of heritage foods to be sold on extra-local markets and please consumers.

According to the analysis, side effects can occur when promoters of valorisation initiatives prompt a priori transformations of the product by selecting only those material and immaterial elements in line with the alleged tastes of new customers and leaving aside the complex social and cultural values that link a product to a specific foodscape. As already observed by Almansouri et al. [29], the triggering of these dynamics can erode and distort distinguishing features of heritage foods and their authenticity.

The review also highlights that the entrance of a product into new commercial circuits can trigger physical and symbolical changes that feedback on the traditional contexts of production, exchange, and consumption. Changes in intangible elements can reverberate on material ones and vice versa with the risk of altering the role of products and disrupting key elements in the identity and resilience of local communities.

Starting from the assumption that every valorisation project triggers alterations and modifications of the foodscape, a more participatory approach might reduce the unintended effects of these changes. However, its effectiveness depends on the willingness and capability of the community to find a balance between the economic expectations of its members and the safeguarding of the common good for the current and future generations.

\section{Conclusions}

This critical literature review investigates the connection between food heritage and socio-cultural sustainability by exploring the unintended effects that may arise in the heritagisation of food and its valorisation. In doing so, it aims at reducing the fragmentation of the debate and offering a critical interpretation of the limits and prospects of food heritage safeguarding and valorisation in the improvement of social and cultural sustainability of the food system.

The findings may be of relevance for various stakeholders and audiences (e.g., scholars, practitioners, and policymakers) in the field of food and gastronomy, acting as a starting point for future reflections on the role of food heritagisation in fostering more sustainable food practices and in tackling global challenges.

Focusing on the dynamics underpinning heritage recognition, legitimisation, and valorisation, the review highlights cross-cutting risks, namely the oversight of tangible and intangible elements of the local food system and the exclusion of key stakeholders from the expected benefits of food heritagisation. These unintended effects may, in turn, undermine the social and cultural sustainability of this process, running the risk of disrupting cultural values, practices and knowledge, and their transmission, as well as hindering the achievement of inclusive and equal improvement of the well-being of the society.

Moreover, the review shows strict interdependence between immaterial and materials elements during food heritagisation and how local and global interactions can shape its outcomes. While these dynamics have already been discussed for situations when heritage foods enter broader socio-economic circuits, the review demonstrates the need to 
explore their impacts in the stages before the commercial valorisation of food heritage in more detail.

In this respect, future studies could examine the impacts of a formal recognition and legitimisation of food and food-related elements on its diversity and variability. Specifically, scholars and institutions should also pay more attention to the continuities and changes in living traditions to keep regional food cultures alive [112].

In addition to this, a thorough understanding of the unintended effects of food heritagisation would benefit from multidisciplinary investigations that explore the perspectives and expectations of specific actors (e.g., producers, promoters of heritage-based projects, food entrepreneurs, and other actors in the food and culinary sectors), the negotiations between them during the heritagisation of food, and the drivers that activate the engagement of local communities in the protection of heritage. To this end, the ethical and moral values that mobilise stakeholders in the local food and gastronomic sector (e.g., social and cultural entrepreneurs and innovators) towards the safeguarding and valorisation of food heritage should be explored in more detail.

This study also has some limitations. It was not a systematic literature review and therefore some important contributions may have been omitted. However, it was not intended to be a thorough review but rather to offer an overview of the literature to critically gather different perspectives on this topic and provide possible directions for future research. Furthermore, the literature search was undertaken using keywords in English, thus excluding the literature in other languages from the analysis.

Future investigations could address this topic in a more systematic way, moving beyond its linguistic range and examining the link between food heritage and socio-cultural sustainability by:

- $\quad$ exploring how food heritage generates and evolves in different places and times;

- investigating new approaches and innovations in the design and implementation of heritage-based projects that seek to guarantee better participation of local communities and more interactions with other stakeholders; and

- identifying social and cultural entrepreneurs and brokers (either community members or external agents) in the safeguarding and promotion of food heritage and comparing their roles and behaviours in different geographical and cultural contexts.

Author Contributions: Conceptualisation, A.P., D.M.Z., M.F.F., and P.C.; methodology, D.M.Z. and M.F.F.; writing—original draft preparation, D.M.Z.; writing—review and editing, A.P., D.M.Z., and M.F.F.; visualisation, D.M.Z.; supervision, A.P. and P.C. All authors have read and agreed to the published version of the manuscript.

Funding: This research received no external funding.

Institutional Review Board Statement: Not applicable.

Informed Consent Statement: Not applicable.

Data Availability Statement: Not applicable.

Conflicts of Interest: The authors declare no conflict of interest.

\section{References}

1. Sjöholm, J. Heritagisation, Re-Heritagisation and De-Heritagisation of Built Environments: The Urban Transformation of Kiruna; Luleå University of Technology: Luleå, Sweden, 2016.

2. Csergo, J. Food as a Collective Heritage Brand in the Era of Globalization. Int. J. Cult. Prop. 2018, 25, 449-468. [CrossRef]

3. Romagnoli, M. Gastronomic Heritage Elements at UNESCO: Problems, Reflections on and Interpretations of a New Heritage Category. Int. J. Intang. Herit. 2019, 14, 157-171. [CrossRef]

4. Geyzen, A. Food Studies and the Heritage Turn: A Conceptual Repertoire. Food Hist. 2014, 12, 67-96. [CrossRef]

5. Bessière, J. Local Development and Heritage: Traditional Food and Cuisine as Tourist Attractions in Rural Areas. Sociol. Rural. 1998, 38, 21-34. [CrossRef]

6. Bessière, J.; Tibere, L. Traditional Food and Tourism: French Tourist Experience and Food Heritage in Rural Spaces. J. Sci. Food Agric. 2013, 93, 3420-3425. [CrossRef] 
7. Timothy, D.J. Heritage Cuisines: Traditions, Identities and Tourism; Routledge: London, UK, 2016.

8. Turner, K.L.; Davidson-Hunt, I.J.; Desmarais, A.A.; Hudson, I. Creole Hens and Ranga-Ranga: Campesino Foodways and Biocultural Resource-Based Development in the Central Valley of Tarija, Bolivia. Agriculture 2016, 6, 41. [CrossRef]

9. Barrionuevo, C.A.; Bernat, E.E.; Velarde, I.J. We Recovered Food Heritage, and Then? Value Enhancement and Promotion of Local Agri-Food Products in Argentina and Spain. Br. Food J. 2019, 121, 3168-3180. [CrossRef]

10. Guan, J.; Gao, J.; Zhang, C. Food Heritagization and Sustainable Rural Tourism Destination: The Case of China's Yuanjia Village. Sustainability 2019, 11, 2858. [CrossRef]

11. Mardatillah, A.; Raharja, S.J.; Hermanto, B.; Herawaty, T. Riau Malay Food Culture in Pekanbaru, Riau Indonesia: Commodification, Authenticity, and Sustainability in a Global Business Era. J. Ethn. Foods 2019, 6, 1-10. [CrossRef]

12. Fusté-Forné, F. Say Gouda, Say Cheese: Travel Narratives of a Food Identity. Int. J. Gastron. Food Sci. 2020, 22, 100252. [CrossRef]

13. Lin, Y.; Bestor, T.C. Embedding Food in Place and Rural Development: Insights from the Bluefin Tuna Cultural Festival in Donggang, Taiwan. J. Rural Stud. 2020, 79, 373-381. [CrossRef]

14. Sidali, K.L.; Morocho, P.; Garrido-Pérez, E.I. Food Tourism in Indigenous Settings as a Strategy of Sustainable Development: The Case of Ilex Guayusa Loes. in the Ecuadorian Amazon. Sustainability 2016, 8, 967. [CrossRef]

15. Dai, S.; Cui, Q.; Xu, H. The Resilience Capabilities of Yumcha Restaurants in Shaping the Sustainability of Yumcha Culture. Sustainability 2018, 10, 3304. [CrossRef]

16. Kapelari, S.; Alexopoulos, G.; Moussouri, T.; Sagmeister, K.J.; Stampfer, F. Food Heritage Makes a Difference: The Importance of Cultural Knowledge for Improving Education for Sustainable Food Choices. Sustainability 2020, 12, 1509. [CrossRef]

17. Derek, M. Nature on a Plate: Linking Food and Tourism within the Ecosystem Services Framework. Sustainability 2021, $13,1687$. [CrossRef]

18. UNESCO. Convention for the Safeguarding of Intangible Cultural Heritage. Available online: https://ich.unesco.org/en/ convention (accessed on 20 June 2021).

19. UNESCO. Introducing Cultural Heritage into the Sustainable Development Agenda; 2013. Available online: http://www.unesco. org/new / fileadmin/MULTIMEDIA/HQ/CLT/images/HeritageENG.pdf (accessed on 20 June 2021).

20. Throsby, D. Sustainability and Culture Some Theoretical Issues. Int. J. Cult. Policy 1997, 4, 7-19. [CrossRef]

21. Soini, K.; Birkeland, I. Exploring the Scientific Discourse on Cultural Sustainability. Geoforum 2014, 51, 213-223. [CrossRef]

22. Petti, L.; Trillo, C.; Makore, B.N. Cultural Heritage and Sustainable Development Targets: A Possible Harmonisation? Insights from the European Perspective. Sustainability 2020, 12, 926. [CrossRef]

23. Finnis, E. Reimagining Marginalized Foods: Global Processes, Local Places; University of Arizona Press: Tucson, AZ, USA, 2012.

24. Brulotte, R.L.; Di Giovine, M.A. Edible Identities: Food as Cultural Heritage; Routledge: London, UK; New York, NY, USA, 2014.

25. Grasseni, C. The Heritage Arena. Reinventing Cheese in the Italian Alps; Berghahn Books: New York, NY, USA, 2016.

26. Parasecoli, F. Knowing Where It Comes from: Labeling Traditional Food to Compete in a Global Market; University of Iowa Press: Iowa City, IA, USA, 2017.

27. Porciani, I. Food Heritage and Nationalism in Europe; Routledge: London, UK, 2019.

28. De-Miguel-Molina, M.; De-Miguel-Molina, B.; Santamarina, V.; Segarra-Oña, M. Intangible Heritage and Gastronomy: The Impact of UNESCO Gastronomy Elements. J. Culin. Sci. Technol. 2016, 14, 293-310. [CrossRef]

29. Almansouri, M.; Verkerk, R.; Fogliano, V.; Luning, P.A. Exploration of Heritage Food Concept. Trends Food Sci. Technol. 2021, 111, 790-797. [CrossRef]

30. Henry, B.M.; Skinningsrud, B.; Vikse, J.; Pękala, P.A.; Walocha, J.A.; Loukas, M.; Tubbs, R.S.; Tomaszewski, K.A. Systematic Reviews versus Narrative Reviews in Clinical Anatomy: Methodological Approaches in the Era of Evidence-Based Anatomy. Clin. Anat. 2018, 31, 364-367. [CrossRef] [PubMed]

31. de Morais Sato, P.; Gittelsohn, J.; Unsain, R.F.; Roble, O.J.; Scagliusi, F.B. The Use of Pierre Bourdieu's Distinction Concepts in Scientific Articles Studying Food and Eating: A Narrative Review. Appetite 2016, 96, 174-186. [CrossRef]

32. Rinaldi, C. Food and Gastronomy for Sustainable Place Development: A Multidisciplinary Analysis of Different Theoretical Approaches. Sustainability 2017, 9, 1748. [CrossRef]

33. Paul, J.; Criado, A.R. The Art of Writing Literature Review: What Do We Know and What Do We Need to Know? Int. Bus. Rev. 2020, 29, 101717. [CrossRef]

34. Denyer, D.; Tranfield, D. Producing a systematic review. In The SAGE Handbook of Organizational Research Methods; Buchanan, D.A., Bryman, A., Eds.; Sage: London, UK, 2009; pp. 671-689.

35. Green, B.N.; Johnson, C.D.; Adams, A. Writing Narrative Literature Reviews for Peer-Reviewed Journals: Secrets of the Trade. J. Chiropr. Med. 2006, 5, 101-117. [CrossRef]

36. Saz-Gil, I.; Bretos, I.; Díaz-Foncea, M. Cooperatives and Social Capital: A Narrative Literature Review and Directions for Future Research. Sustainability 2021, 13, 534. [CrossRef]

37. O'Neill, M.M.; Booth, S.R.; Lamb, J.T. Using NVivo ${ }^{\mathrm{TM}}$ for Literature Reviews: The Eight Step Pedagogy (N7+1). Qual. Rep. 2018, 23, 21-39. [CrossRef]

38. Elo, S.; Kääriäinen, M.; Kanste, O.; Pölkki, T.; Utriainen, K.; Kyngäs, H. Qualitative Content Analysis: A Focus on Trustworthiness. SAGE Open 2014, 4, 1-10. [CrossRef]

39. Bazeley, P. Qualitative Data Analysis with NVivo; SAGE Publications: Los Angeles, CA, USA, 2007. 
40. Bowen, S.; De Master, K. New Rural Livelihoods or Museums of Production? Quality Food Initiatives in Practice. J. Rural Stud. 2011, 27, 73-82. [CrossRef]

41. Matta, R. Valuing Native Eating: The Modern Roots of Peruvian Food Heritage. Anthropol. Food 2013, S8. [CrossRef]

42. Littaye, A. The Multifunctionality of Heritage Food: The Example of Pinole, a Mexican Sweet. Geoforum 2016, 76, 11-19. [CrossRef]

43. Bowen, S.; De Master, K. Wisconsin's "Happy Cows"? Articulating Heritage and Territory as New Dimensions of Locality. Agric. Hum. Values 2014, 31, 549-562. [CrossRef]

44. Besky, S. The Labor of Terroir and the Terroir of Labor: Geographical Indication and Darjeeling Tea Plantations. Agric. Hum. Values 2014, 31, 83-96. [CrossRef]

45. Bérard, L.; Casabianca, F.; Montel, M.-C.; Agabriel, C.; Bouche, R. Salers Protected Designation of Origin Cheese, France. The Diversity and Paradox of Local Knowledge in Geographical Indications. Cult. Hist. Digit. J. 2016, 5, e006. [CrossRef]

46. Teigen De Master, K.; LaChance, J.; Bowen, S.; MacNell, L. Terroir in Transition: Environmental Change in the Wisconsin Artisanal Cheese and New England Oyster Sectors. Sustainability 2019, 11, 2969. [CrossRef]

47. Muchnik, J.; Cerdan, C.; Biénabe, E. Food Identity/Food Quality: Insights from the "Coalho" Cheese in the Northeast of Brazil. Anthropol. Food 2005, S4. [CrossRef]

48. Parasecoli, F.; Tasaki, A. Shared Meals and Food Fights: Geographical Indications, Rural Development, and the Environment. Environ. Soc. Adv. Res. 2011, 2, 106-123. [CrossRef]

49. Timothy, D.J.; Ron, A.S. Understanding Heritage Cuisines and Tourism: Identity, Image, Authenticity, and Change. J. Herit. Tour. 2013, 8, 99-104. [CrossRef]

50. Aistara, G. Authentic Anachronisms. Gastron. J. Food Cult. 2014, 14, 7-16. [CrossRef]

51. Matta, R. Food Incursions into Global Heritage: Peruvian Cuisine's Slippery Road to UNESCO. Soc. Anthropol. 2016, 24, 338-352. [CrossRef]

52. Welz, G. Contested Origins: Food Heritage and the European Union's Quality Label Program. Food Cult. Soc. 2013, 16, 265-279. [CrossRef]

53. May, S. Cheese, Commons and Commerce: On the Politics and Practices of Branding Regional Food. Ethnol. Eur. 2013, $43,62-77$. [CrossRef]

54. Bortolotto, C.; Ubertazzi, B. Editorial: Foodways as Intangible Cultural Heritage. Int. J. Cult. Prop. 2018, 25, 409-418. [CrossRef]

55. Porciani, I.; Montanari, M. Careful with Heritage. In Food Heritage and Nationalism in Europe; Porciani, I., Ed.; Routledge: London, UK, 2019; pp. 207-213.

56. Matta, R. Documenting the UNESCO Feast: Stories of Women's 'Empowerment' and Programmatic Cooking. Soc. Anthropol. 2021, 29, 188-204. [CrossRef]

57. Grasseni, C. La Patrimonializzazione Del Cibo. Prospettive Critiche e Convergenze 'sul Campo'. Voci 2013, 10, 87-110.

58. Cheung, S.C.H. From Foodways to Intangible Heritage: A Case Study of Chinese Culinary Resource, Retail and Recipe in Hong Kong. Int. J. Herit. Stud. 2013, 19, 353-364. [CrossRef]

59. Coombe, R.J.; Aylwin, N. Bordering Diversity and Desire: Using Intellectual Property to Mark Place-Based Products. Environ. Plan. A Econ. Sp. 2011, 43, 2027-2042. [CrossRef]

60. Leitch, A. Slow Food and the Politics of Pork Fat: Italian Food and European Identity. Ethnos 2003, 68, 437-462. [CrossRef]

61. Mak, S.-W. The Revival of Traditional Water Buffalo Cheese Consumption: Class, Heritage and Modernity in Contemporary China. Food Foodways 2014, 22, 322-347. [CrossRef]

62. Sammells, C.A. Reimagining Bolivian Cuisine: Haute Traditional Food and Its Discontents. Food Foodways 2019, $27,338-352$. [CrossRef]

63. Klein, J.A. Heritagizing Local Cheese in China: Opportunities, Challenges, and Inequalities. Food Foodways 2018, $26,63-83$. [CrossRef]

64. Badii, M. Traditional Food Heritage in Contemporary Tuscany. Local Networks and Global Policies around the Zolfino Bean. Ethnologies 2013, 35, 129-145. [CrossRef]

65. Wincott, A. Heritage in Danger or Mission Accomplished? Food Cult. Soc. 2015, 18, 569-588. [CrossRef]

66. Vitrolles, D. When Geographical Indication Conflicts with Food Heritage Protection the Case of Serrano Cheese from Rio Grande Do Sul, Brazil. Anthropol. Food 2011, S8. [CrossRef]

67. de St. Maurice, G.; Miller, T.L. Less Palatable, Still Valuable: Taste, Crop Agrobiodiversity, and Culinary Heritage. Food Cult. Soc. 2017, 20, 193-200. [CrossRef]

68. Zocchi, D.M.; Fontefrancesco, M.F. Traditional Products and New Developments in the Restaurant Sector in East Africa. The Case Study of Nakuru County, Kenya. Front. Sustain. Food Syst. 2020, 4, 599138. [CrossRef]

69. Grey, S.; Newman, L. Beyond Culinary Colonialism: Indigenous Food Sovereignty, Liberal Multiculturalism, and the Control of Gastronomic Capital. Agric. Hum. Values 2018, 35, 717-730. [CrossRef]

70. Pfeilstetter, R. Heritage Entrepreneurship. Agency-Driven Promotion of the Mediterranean Diet in Spain. Int. J. Herit. Stud. 2015, 21, 215-231. [CrossRef]

71. Avieli, N. The Hummus Wars: Local Food, Guinness Records and Palestinian-Israeli Gastropolitics. In Cooking Cultures: Convergent Histories of Food and Feeling; Banerjee-Dube, I., Ed.; Cambridge University Press: Cambridge, UK, 2016; pp. $39-57$.

72. Nabhan, G.P.; Walker, D.; Moreno, A.M. Biocultural and Ecogastronomic Restoration: The Renewing America's Food Traditions Alliance. Ecol. Restor. 2010, 28, 266-279. [CrossRef] 
73. Carlisle, L. Making Heritage: The Case of Black Beluga Agriculture on the Northern Great Plains. Ann. Am. Assoc. Geogr. 2016, 106, 130-144. [CrossRef]

74. Sidali, K.L.; Kastenholz, E.; Bianchi, R. Food Tourism, Niche Markets and Products in Rural Tourism: Combining the Intimacy Model and the Experience Economy as a Rural Development Strategy. J. Sustain. Tour. 2015, 23, 1179-1197. [CrossRef]

75. Jones, B.M. Producing Heritage: Politics, Patrimony, and Palatability in the Reinvention of Lowcountry Cuisine. Food Cult. Soc. 2017, 20, 217-236. [CrossRef]

76. McDonell, E. Creating the Culinary Frontier: A Critical Examination of Peruvian Chefs' Narratives of Lost/Discovered Foods. Anthropol. Food 2019, S14. [CrossRef]

77. Pereira, L.M.; Calderón-Contreras, R.; Norström, A.V.; Espinosa, D.; Willis, J.; Guerrero Lara, L.; Khan, Z.; Rusch, L.; Correa Palacios, E.; Pérez Amaya, O. Chefs as Change-Makers from the Kitchen: Indigenous Knowledge and Traditional Food as Sustainability Innovations. Glob. Sustain. 2019, 2, e16. [CrossRef]

78. Cohen, E.; Cohen, S.A. Authentication: Hot and Cool. Ann. Tour. Res. 2012, 39, 1295-1314. [CrossRef]

79. Smith, L. Uses of Heritage; Routledge: London, UK, 2006.

80. Bowen, S. Embedding Local Places in Global Spaces: Geographical Indications as a Territorial Development Strategy. Rural Sociol. 2010, 75, 209-243. [CrossRef]

81. Maye, D.; Kirwan, J.; Schmitt, E.; Keech, D.; Barjolle, D. PDO as a Mechanism for Reterritorialisation and Agri-Food Governance: A Comparative Analysis of Cheese Products in the UK and Switzerland. Agriculture 2016, 6, 54. [CrossRef]

82. West, H.G.; Domingos, N. Gourmandizing Poverty Food: The Serpa Cheese Slow Food Presidium. J. Agrar. Chang. 2012, 12, 120-143. [CrossRef]

83. MacDonald, K.I. The Morality of Cheese: A Paradox of Defensive Localism in a Transnational Cultural Economy. Geoforum 2013, 44, 93-102. [CrossRef]

84. Littaye, A. The Role of the Ark of Taste in Promoting Pinole, a Mexican Heritage Food. J. Rural Stud. 2015, 42, 144-153. [CrossRef]

85. Grasseni, C. Re-Inventing Food: Alpine Cheese in the Age of Global Heritage. Anthropol. Food 2011, 8, 6819. [CrossRef]

86. Koohafkan, P.; Altieri, M.A. Forgotten Agricultural Heritage: Reconnecting Food Systems and Sustainable Development; Taylor and Francis Inc.: Rome, Italy, 2016.

87. Pieroni, A.; Pawera, L.; Shah, G. Gastronomic Ethnobiology. In Introduction to Ethnobiology; Albuquerque, U.P., Nóbrega Alves, R.R., Eds.; Springer: Cham, Switzerland, 2016; pp. 53-62.

88. Bérard, L.; Marchenay, P. Local Products and Geographical Indications: Taking Account of Local Knowledge and Biodiversity. Int. Soc. Sci. J. 2006, 58, 109-116. [CrossRef]

89. Ray, C. Culture, Intellectual Property and Territorial Rural Development. Sociol. Rural. 1998, 38, 3-20. [CrossRef]

90. Dabezies, J.M. Heritagization of Nature and Its Influence on Local Ecological Knowledge in Uruguay. Int. J. Herit. Stud. 2018, 24, 828-842. [CrossRef]

91. West, H.G. Artisanal Foods and the Cultural Economy: Perspectives on Craft, Heritage, Authenticity and Reconnection. In The Handbook of Food and Anthropology; Watson, J.L., Klein, J.A., Eds.; Bloomsbury: London, UK, 2016; pp. 406-434.

92. Gyimóthy, S. The Reinvention of Terroir in Danish Food Place Promotion. Eur. Plan. Stud. 2017, 25, 1200-1216. [CrossRef]

93. van Esterik, P. From Hunger Foods to Heritage Foods: Challenges to Food Localization in Lao PDR. In Fast Food/Slow Food: The Cultural Economy of the Global Food System; Wilk, R., Ed.; Altamira Press: Lanham, MD, USA, 2006; pp. 83-96.

94. Chera, M. Transforming Millets: Strategies and Struggles in Changing Taste in Madurai. Food Cult. Soc. 2017, 20, 303-324. [CrossRef]

95. Wincott, A. Treasure in the Vault: The Guardianship of 'Heritage' Seeds, Fruit and Vegetables. Int. J. Cult. Stud. 2018, 21, 627-642. [CrossRef]

96. Bardone, E.; Spalvēna, A. European Union Food Quality Schemes and the Transformation of Traditional Foods into European Products in Latvia and Estonia. Appetite 2019, 135, 43-53. [CrossRef] [PubMed]

97. Demossier, M. The Europeanization of Terroir: Consuming Place, Tradition and Authenticity. In European Identity and Culture: Narratives of Transnational Belonging; Friedman, R., Thiel, M., Eds.; Routledge: New York, NY, USA, 2016; pp. $119-137$.

98. Barham, E. Translating Terroir: The Global Challenge of French AOC Labeling. J. Rural Stud. 2003, 19, 127-138. [CrossRef]

99. Zocchi, D.M.; Volpato, G.; Chalo, D.; Mutiso, P.; Fontefrancesco, M.F. Expanding the Reach: Ethnobotanical Knowledge and Technological Intensification in Beekeeping among the Ogiek of the Mau Forest, Kenya. J. Ethnobiol. Ethnomed. 2020, 16, 57. [CrossRef]

100. Cox Hall, A. Heritage Prospecting and the Past as Future(s) in Peru. J. Lat. Am. Caribb. Anthropol. 2019, 24, 331-350. [CrossRef]

101. Rangnekar, D. Remaking Place: The Social Construction of a Geographical Indication for Feni. Environ. Plan. A Econ. Sp. 2011, 43, 2043-2059. [CrossRef]

102. Mancini, M.C. Geographical Indications in Latin America Value Chains: A “Branding from below" Strategy or a Mechanism Excluding the Poorest? J. Rural Stud. 2013, 32, 295-306. [CrossRef]

103. Mariani, M.; Cerdan, C.; Peri, I. Origin Food Schemes and the Paradox of Reducing Diversity to Defend It. Sociol. Rural. 2021, 61, 465-490. [CrossRef]

104. Zocchi, D.M.; Piochi, M.; Cabrino, G.; Fontefrancesco, M.F.; Torri, L. Linking Producers' and Consumers' Perceptions in the Valorisation of Non-Timber Forest Products: An Analysis of Ogiek Forest Honey. Food Res. Int. 2020, 137, 109417. [CrossRef] [PubMed] 
105. Bendix, R. Heritage between Economy and Politics. In Intangible Cultural Heritage; Smith, L., Akagawa, N., Eds.; Routledge: London, UK, 2009; pp. 253-269.

106. Kirshenblatt-Gimblett, B. Intangible Heritage as Metacultural Production1. Mus. Int. 2004, 56, 52-65. [CrossRef]

107. Avieli, N. What Is 'Local Food?' Dynamic Culinary Heritage in the World Heritage Site of Hoi an, Vietnam. J. Herit. Tour. 2013, 8, 120-132. [CrossRef]

108. Herzfeld, M. The Body Impolitic: Artisans and Artifice in the Global Hierarchy of Value; University of Chicago Press: Chicago, IL, USA, 2004.

109. DeSoucey, M. Gastronationalism: Food Traditions and Authenticity Politics in the European Union. Am. Sociol. Rev. 2010, 75, 432-455. [CrossRef]

110. Evans, P. Development as Institutional Change: The Pitfalls of Monocropping and the Potentials of Deliberation. Stud. Comp. Int. Dev. 2004, 38, 30-52. [CrossRef]

111. Grasseni, C. Slow Food, Fast Genes: Timescapes of Authenticity and Innovation in The Anthropology of Food. Camb. Anthropol. 2005, 25, 79-94.

112. West, H.G. Crafting Innovation: Continuity and Change in the "Living Traditions" of Contemporary Artisan Cheesemakers. Food Foodways 2020, 28, 91-116. [CrossRef] 